PERM JOURNAL OF PETROLEUM AND MINING ENGINEERING

ВЕСТНИК ПНИПУ. ГЕОЛОГИЯ. НЕФТЕГАЗОВОЕ И ГОРНОЕ ДЕЈО

ISSN 2224-9923

Volume/ Toм 18 №1, 2018

http://vestnik.pstu.ru/geo/

УДК 622.276 .72

Article / Статья

(C) PNRPU / ПНИПУ, 2018

\title{
THE EFFICIENCY ASSESSMENT OF THE "COLD FLOW" METHOD AGAINST THE DEPOSITION OF ASPHALTENES, RESINS AND PARAFFINS
}

\section{Pavel Yu. Ilyushin, Aleksandr V. Lekomtsev, Tatyana S. Ladeyshchikova, Ruslan M. Rakhimzyanov}

Perm National Research Polytechnic University (29 Komsomolskiy av., Perm, 614990, Russian Federation)

\section{ОЦЕНКА ЭФФЕКТИВНОСТИ МЕТОДА «ХОЛОДНЫЙ ПОТОК» В БОРЬБЕ С АСФАЛЬТЕНОСМОЛОПАРАФИНОВЫМИ ОТЛОЖЕНИЯМИ}

\section{П.Ю. Илюшин, А.В. Лекомцев, Т.С. Ладейщикова, Р.М. Рахимзянов}

Пермский национальный исследовательский политехнический университет (614990, Россия, г. Пермь, Комсомольский пр., 29)

Received / Получена: 10.07.2018. Accepted / Принята: 03.09.2018. Published / Опубликована: 28.09.2018

Key words:

mechanisms of formation of deposition of asphaltenes, resins and paraffins, DARP, molecular diffusion, temperature gradient, hydraulic calculation, cold flow, equation of fluid state, rheological curve, component composition, viscosity, flow temperature.

\begin{abstract}
Mechanisms of formation of deposition of asphaltenes, resins and paraffins (DARP) are considered. Molecular diffusion based on the influence of the temperature gradient is the main mechanism for DARP formation. The analysis of existing methods against DARP is given. Modern methods of DARP prevention that affect the temperature gradient are aimed at maintaining the oil temperature above the crystallization temperature of paraffin. The cold flow method is an alternative control method which involves cooling the oil to a surrounding temperature. The purpose of the work is to assess the effectiveness of the cold flow method against DARP; its advantages and disadvantages are revealed. In order to assess the effectiveness of the proposed method. The sample of oil and produced water was taken at the pumping station. Using gas chromatography, the fractional composition of an oil sample was determined using the SimDis method. Using a calibration table, a component composition of oil up to $\mathrm{C}_{52}$ was calculated using values of boiling point and equations of fluid state were formed in PVTsim software. Rheological studies of the transported oil are carried out. Based on results of laboratory studies in OLGA software package, a hydraulic calculation of the pipeline was performed for various values of the flow temperature using the "Wax deposition" paraffin deposition module on the Matzain model. Thus, having the flow with temperature equal to the ambient temperature, in 10 days $5.6 \mathrm{~kg}$ of paraffin is formed on pipeline walls, whereas in the current conditions it is $100 \mathrm{~kg}$.

As a result, it is established that the effectiveness of the application of the cold flow method against DARP is $94 \%$. Proposed method can significantly reduce production costs associated with paraffin oil transportation.
\end{abstract}

Рассмотрены механизмы образования асфальтеносмолопарафиновых отложений (АСПО). Основным механизмом формирования АСПО является молекулярная диффузия, основанная на влиянии температурного градиента. Проведен анализ существующих методов борьбы с АСПО. Современные методы предупреждения АСПО, воздействующие на температурный градиент, направлены на поддержание температуры нефти выше температуры кристаллизации парафина. Альтернативным способом борьбы является метод «холодный поток», предполагающий охлаждение нефти до температуры окружающей среды. Целью работы является оценка эффективности применения метода «холодный поток» в борьбе с АСПО, выявлены его преимущества и недостатки. Для оценки эффективности предлагаемого метода построена модель существующего трубопровода от дожимной насосной станции до установки предварительного сброса воды. На дожимной насосной станции отобран образец нефти и пластовой воды. С помощью газовой хроматографии методом SimDis определен фракционный состав образца нефти. По значениям температуры кипения с помощью калибровочной таблицы рассчитан компонентный состав нефти до С52 и сформированы уравнения состояния флюидов в программном продукте PVTsim. Проведены реологические исследования транспортируемой нефти. На основе результатов лабораторных исследований в программном комплексе OLGA выполнен гидравлический расчет трубопровода при различных значениях температуры потока с использованием модуля осаждения парафина Wax deposition на модели Matzain. Таким образом, при температуре потока, равной температуре окружающей среды, за 10 дней на стенках трубопровода формируется 5,6 кг парафина, тогда как в текущих условиях - 100 кг.

В результате работы установлено, что эффективность применения метода «холодный поток» в борьбе с АСПО составляет 94 \%. Его использование может значительно уменьшить издержки производства, связанные с транспортировкой парафинистой нефти.

Pavel Yu. Ilyushin - PhD in Engineering, Associate Professor, Director of the Scientific and Educational Center "Geology and Development of Oil and Gas Fields" (tel.: +007 34223910 70, e-mail: ilushin-pavel@yandex.ru).

Aleksandr V. Lekomtsev - PhD in Engineering, Associate Professor, Senior Research Fellow of the Scientific and Educational Center "Geology and Development of Oil and Gas Fields" (tel.: +007 34223910 70, e-mail: alex.lekomtsev@mail.ru).

Tatyana S. Ladeyshchikova - MSc student of the Mining and Oil Faculty (tel.: +007 95264328 50, e-mail: ladeyshikowa.tanya@yandex.ru). The contact person or correspondence.

Ruslan M. Rakhimzyanov - PhD student, Junior Research Fellow of the Scientific and Educational Center "Geology and Development of Oil and Gas Fields" (tel.: +007 3422391070 , e-mail: rusenish@inbox.ru).

Илюшин Павел Юрьевич - кандидат технических наук, доцент, директор научно-образовательного центра «Геология и разработка нефтяных и газовых месторождений» (тел.: +007342 23910 70, e-mail: ilushin-pavel@yandex.ru).

Лекомцев Александр Викторович - кандидат технических наук, доцент, старший научный сотрудник научно-образовательного центра «Геология и разработка нефтяных и газовых месторождений» (тел.: +007342 23910 70, e-mail: alex.lekomtsev@mail.ru).

Ладейщикова Татьяна Сергеевна - студент магистратуры горно-нефтяного факультета (тел.: +007 9526432850 , e-mail: ladeyshikowa.tanya@yandex.ru). Контактное лицо для переписки.

Рахимзянов Руслан Маратович - аспирант, младший научный сотрудник научно-образовательного центра «Геология и разработка нефтяных и газовых месторождений» (тел.: +007342 23910 70, e-mail: rusenish@inbox.ru). 


\section{Introduction}

Pipeline transportation is the integral part of the fuel and energy complex of Russia. Nowdays, more than $95 \%$ of oil is transported via pipelines. However, this method of transportation has a number of disadvantages such as deposition of asphaltenes, resins and paraffins (DARP) during the transportation of crude oil. Nearly every fifth accident is caused by precipitation of DARP [1]. A decrease in pressure and temperature as well as oil degassing create conditions required for precipitation of DARP. If the temperature of oil is higher than the crystallization temperature of paraffin, then paraffin components are in the dissolved as a liquid phase of the oil system. A decrease in temperature forces the components to crystallize out of the oil and form spatial structures [2-6].

DARP decrease the capacity and can totally plug and break the pipeline, which leads to disastrous environmental consequences. Besides, there is a decrease in effectivness of systems, efficiency of operation of pumping facilities and time between overhauls. All these consequences entail significant economic costs to restore the ecology and the performance of the oil gathering system [7-8].

All the factors mentioned above make it clear that environmental safety, smooth-running, durability and economical operation of pipelines directly depend on timely prevention of DARP precipitation. Today, the greatest attention is paid to the prevention and control of sediments. The issue of reducing and eliminating paraffin deposits remains unresolved [9].

In order to select the most effective method to fight with DARP it is necessary to have an idea about the mechanisms its formation. That will allow to carry out the selection of the most effective method of reducing the amount of paraffin deposits.

\section{Mechanisms of DARP development}

The mechanism of development of paraffin deposits consists in the release and growth of paraffin crystals on the surface in contact with oil and then on the resulting DARP layer. There are various mechanisms for the precipitation of paraffin hydrocarbons, including molecular diffusion, shear dispersion, Brownian diffusion, and gravitational sedimentation [10].

The mechanism of molecular diffusion is based on the transfer of dissolved paraffin components from the volume of oil to the wall of the pipeline. The remaining mechanisms consider the movement of suspended paraffin particles released in the volume of oil as a result of lowering the oil temperature below the crystallization temperature of paraffin [11]. However, paraffin crystals developed in the volume of oil practically do not participate in the process of DARP formation, but are transferred in the oil flow in a suspended state. Many results in the dynamics of dissolved particles indicate that particles located in a viscous layer near a wall are usually re-captured into a volume flow under the action of a lifting force created by a turbulent flow known as "Saffman lifting force" $[12,13]$.

Based on extensive experimental observations of the deposition of paraffin over the past few decades, we note that molecular diffusion is the main mechanism of DARP development [14-16]. The diffusion mechanism for DARP development is considered next (Fig. 1). Oil, in contact with the cooled wall of the pipeline, begins to cool. A radial temperature gradient arises between the inner wall of the pipeline and the boundary layer of the flow (see Fig. 1a). When the temperature drops below the saturation temperature of the oil with paraffin, the process of crystallization of paraffinic components (PC), which are in a dissolved state, begins and the precipitation of paraffin crystalson the internal surface of the pipeline. As a result, the concentration of dissolved PC at the pipe wall is reduced compared with the concentration in the volume of oil - a gradient of concentration of dissolved paraffin appears. Under the action of the diffusion process, the dissolved PCs move from a region with a high concentration to a region with a low concentration, i.e. from the volume of oil to the wall, where the crystallization process continues (see Fig. 1b). The diffusion coefficient of $\mathrm{PC}$ in oil usually ranges from $10^{-10}$ to $10^{-9} \mathrm{~m}^{2} / \mathrm{s}$ [17] .

When the first layer of paraffin deposits on the wall is finished, the process of deposition of paraffin crystals continues, but now on the 
boundary surface of the oil region (see Fig. 1c). Not all the PCs crystallize when they reach the pipeline wall. Some of them continue to diffuse in the layer of paraffin deposits. This phenomenon is known as "sediment aging". Internal diffusion of dissolved PCs leads to an increase in the paraffin fractioning the sediment layer (see Fig. 1d). Consequently, a large part of PCs in the layer of paraffin deposits with an increased solubility limit may further crystallize, leading to an increase in the hardness of the DARP layer.

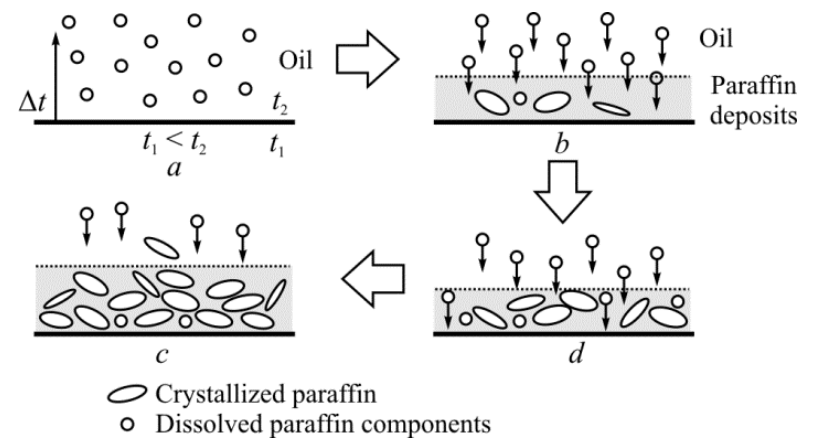

Fig. 1. Schematic representation of the diffusion mechanism of DARP development

Thus, the main driving force during the DARP development is the temperature gradient.

By affecting it, it is possible to change change the amount of paraffin deposits that form on the inner surface of the pipeline.

\section{Cold flow}

There are two directions where fight against DARP is occur such as the prevention of the formation of deposits and the removal of the formed deposits. The most rational use of methods for preventing the formation of DARP, as this eliminates pipeline downtime and, as a consequence, significant economic losses to restore the efficiency of the system for collecting and transporting oil. Measures to prevent the formation of paraffin deposits involve the use of chemical and physical methods, as well as the use of protective coatings [18]. A protective coating is expensive, and the application process is time consuming. Chemical methods are based on the addition of chemical reagents to the pumped product that prevent DARP development [19]. The main disadvantages of chemical methods are the high cost and difficulty of selecting an effective reagent. Physical methods are based on the effects of mechanical and ultrasonic vibrations on the products being transported, as well as the effects of electric, magnetic and electromagnetic fields. The disadvantages of physical methods include their high cost and complexity in technical performance [20-24].

The cold flow method is an alternative to modern measures to prevent the formation of DARP, which involves the transportation of oil cooled to ambient temperature. This method is more effective than other methods of preventing DARP development, as it affects the cause of the formation of paraffin deposits - temperature gradient [25]. The cold flow method can find its application in pipelines, where the use of mechanical cleaning devices is not possible. These include variable-diameter pipelines, as well as pipelines with constrictions, sharp turns and other local resistances.

The use of this method in underwater pipelines and in permafrost areas should also be considered. Underwater pipelines cleaning is a difficult operation from a technical and organizational point of view. In the event of an unplanned stop of the in-line cleaning device, the fluid is cooled and crosslinked gels are formed [26]. To restart the pipeline, great pressure will be required to destroy the formed gels. If the pressure required to restart the pipeline exceeds the allowable one, then the line must be left or completely replaced, which entails significant economic losses. During the operation of pipelines in permafrost zones, dynamic equilibrium disturbances occur, accompanied by heaving and subsidence of freezing, thawing soils. Intensive processes of watering and bogging occur, which leads to the destruction of the embankment and the emersion of the pipeline [27-34].

All the cases given above can use the cold flow method, which will reduce the risk of accidents and prevent significant economic losses. However, when considering this method, it is necessary to consider the viscosity of the oil, which increases when the flow is cooled and leads to an increase in the pressure required to transport the fluid.

\section{Modeling paraffin precipitation in cold flow conditions}

In order to evaluate the effectivenes of the cold flow method for preventing the formation of paraffin 
oil hydraulic calculation conducted in the simulator OLGA multiphase flow using paraffin deposition module Wax Deposition in MATZAIN model.

The Wax Deposition module allows you to simulate the process of separating paraffin from oil and deposition on the inner surface of the pipeline wall. The crystallization and melting of paraffinic hydrocarbons are calculated depending on pressure and temperature. The theory of molecular diffusion of dissolved paraffin due to heat transfer between the fluid and the wall, as well as the transfer of precipitated paraffin as a result of shear dispersion, is the basis of the mechanism of paraffin hydrocarbon deposition in the MATZAIN model [35].

The system of oil transportation from a pumping station to a water separation unit was selected as an object to study. The pipeline considered is characterized by intense precipitation of paraffin. Separated oil with a water content of $15 \%$ is transported through a steel pipeline with a diameter of $219 \mathrm{~mm}$ to a distance of 5,282 $\mathrm{m}$ with a flow rate of $7,175 \mathrm{~m}^{3} /$ day. The pressure at the inlet of the PWH is $0.1 \mathrm{MPa}$.

A sample of oil and produced water was taken at the pumping station to determine the parameters required as input data when calculating in OLGA. Using gas chromatography, the fractional composition of an oil sample was determined using the SimDis method. Then the component composition of oil was calculated up to C52 (see Table) using the calibration table.

Using the PVTsimfluid software phase diagram was built (Fig. 2).

Transported water-oil emulsion was studied in order to determine rheological parameters using balance mixtures of oil and water at the temperature of $5^{\circ} \mathrm{C}$. Density of oil is $835 \mathrm{~kg} / \mathrm{m}^{3}$, density of water is $1,087 \mathrm{~kg} / \mathrm{m}^{3}$. As a result of research, a rheological curve is obtained, shown in Fig. 3.

Hydraulic design was carried out for 10 days at various values of the flow temperature. According to the current state, the oil flow at the outlet from the pumping station has a temperature of $14.44^{\circ} \mathrm{C}$. The pipeline is laid underground. The ambient temperature is $2.1{ }^{\circ} \mathrm{C}$.

As a result of the design, graphs of the distribution of the layer of paraffin deposits along the pipeline, are presented in Fig. 4
Table

Oil composition

\begin{tabular}{|c|c|c|}
\hline Component & Component mass, $\mathrm{g}$ & Content, mas. \% \\
\hline C5 & 2.533 & 2.58 \\
\hline C6 & 2.788 & 2.84 \\
\hline C7 & 4.001 & 4.08 \\
\hline C8 & 4.846 & 4.95 \\
\hline C9 & 4.849 & 4.95 \\
\hline C10 & 4.654 & 4.75 \\
\hline C11 & 4.411 & 4.50 \\
\hline C12 & 3.805 & 3.88 \\
\hline C13 & 4.279 & 4.37 \\
\hline C14 & 4.136 & 4.22 \\
\hline C15 & 3.902 & 3.98 \\
\hline C16 & 3.716 & 3.79 \\
\hline C17 & 3.440 & 3.51 \\
\hline C18 & 3.132 & 3.20 \\
\hline C20 & 6.023 & 6.15 \\
\hline C24 & 10.180 & 10.39 \\
\hline C28 & 7.859 & 8.02 \\
\hline C32 & 6.207 & 6.33 \\
\hline C36 & 4.610 & 4.70 \\
\hline C40 & 3.367 & 3.44 \\
\hline C50 & 4.758 & 4.85 \\
\hline C52 & 0.504 & 0.51 \\
\hline Total & 98 & 100 \\
\hline & & \\
\hline
\end{tabular}

OILGAS DNS EOS $=\mathrm{PR}$

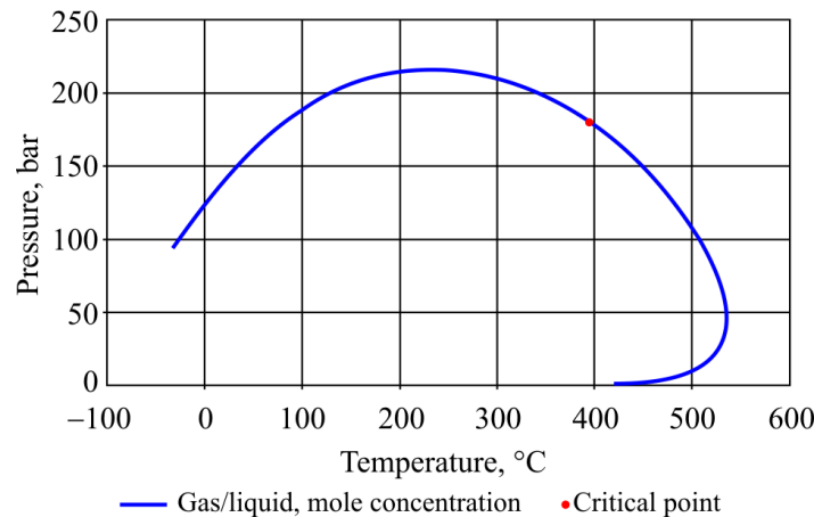

Fig. 2. Phase Fluid Diagram

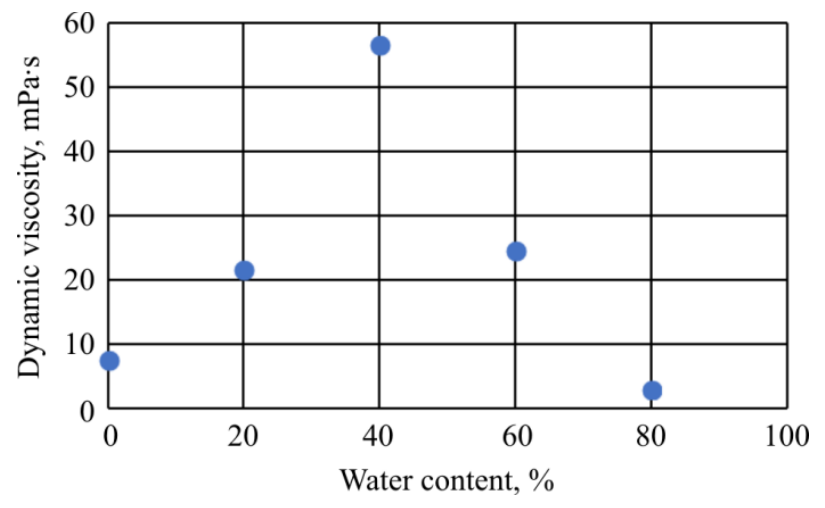

Fig. 3. Dependence of the emulsion dynamic viscosity on water content 

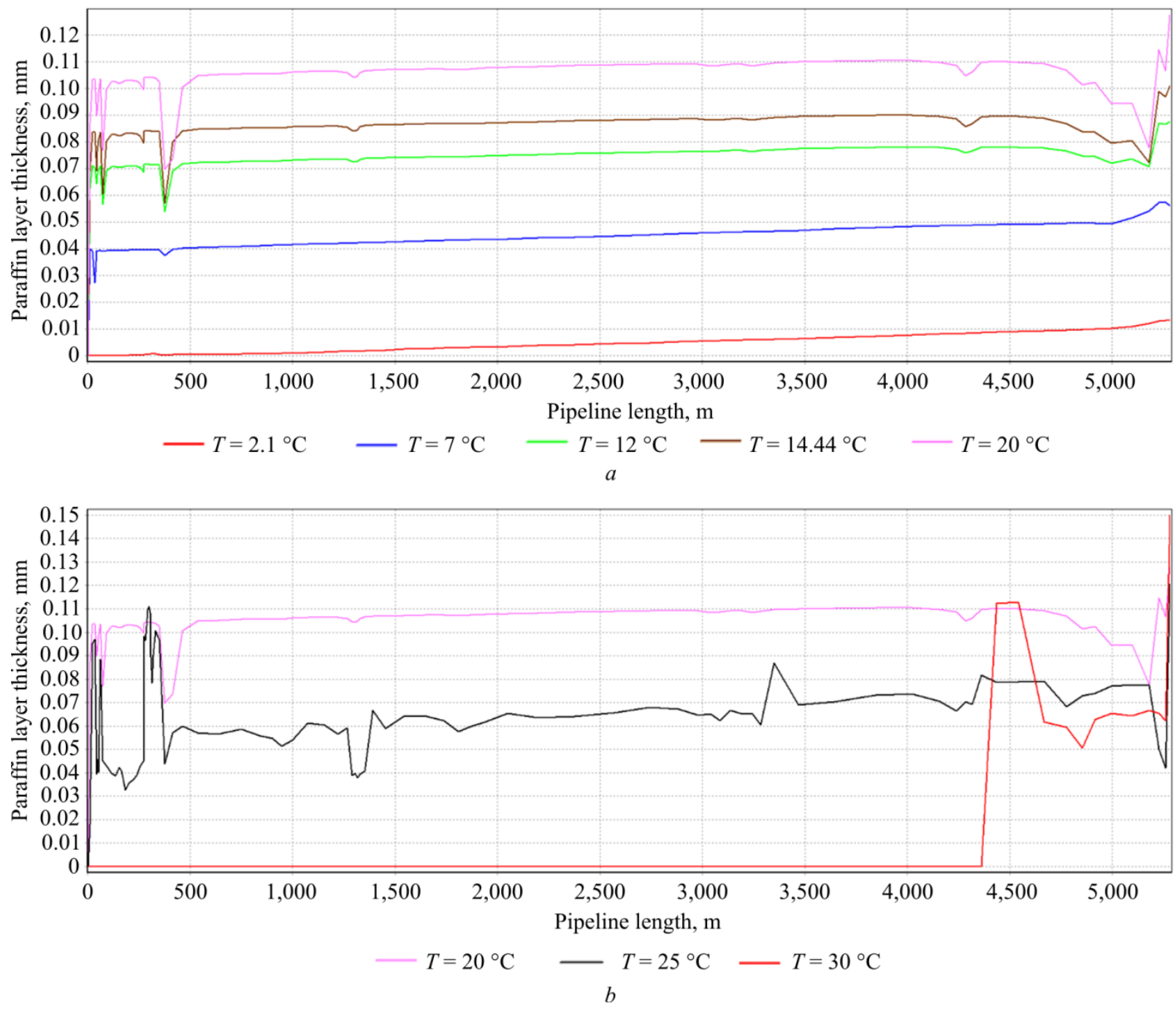

Fig. 4. Graph of the DARP layer thickness distribution along the pipeline at the temperature of pumped liquid: $a$ - up to $20^{\circ} \mathrm{C} ; b-$ from $20^{\circ} \mathrm{C}$

At the flow temperature of $14.44{ }^{\circ} \mathrm{C}$, a paraffin layer $0.02 \mathrm{~mm}$ thick is deposited on the inner surface of the pipe along the entire length (Fig. 4a). The lower the temperature of the oil the lower the thickness of the DARP layer. At a temperature of $2.1{ }^{\circ} \mathrm{C}$ maximum thickness of DARP layer is 7 times less than at temperature of $14.44{ }^{\circ} \mathrm{C}$.

As the temperature increases from $20^{\circ} \mathrm{C}$, the geometry of the paraffin distribution layer varies (see. Fig. $4 b$ ). At $30^{\circ} \mathrm{C}$ the minimum amount of paraffin is deposited along the entire length of the pipeline, the main part falls at the end. This is caused by the fact that paraffin approaches the melting point of $31{ }^{\circ} \mathrm{C}$. Fig. 5 shows a plot of precipitated paraffin mass and pumping pressure versus flow temperature.

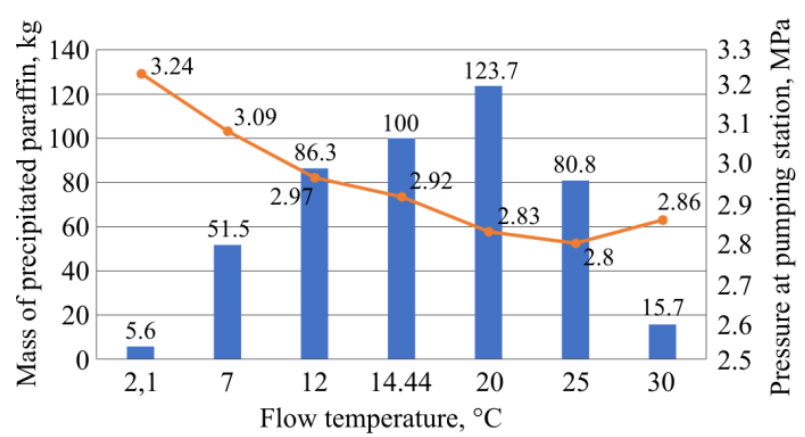

- Mass of precipitated paraffin, $\mathrm{kg} \multimap$ Pressure at pumping station, MPa

Fig. 5. Dependance of deposited mass of paraffin and pumping pressure from the flow temperature

The graph (Fig. 5) shows a tendency to decrease the mass of precipitated paraffin with decreasing flow temperature. At the flow temperature of $2.1{ }^{\circ} \mathrm{C}, 5.6 \mathrm{~kg}$ of paraffin is precipitated on the pipeline wall in 10 days, while 
under current conditions $\left(14.44{ }^{\circ} \mathrm{C}\right)$ the mass of paraffin deposited is $100 \mathrm{~kg}$.

Thus, in order to reduce the amount of DARP, it is necessary to cool the oil to the temperature of the pipeline wall, thereby eliminating the effect of the temperature gradient. However, the lower the oil temperature the higher its viscosity and as a result, the higher the required pressure for transporting the liquid to the water separation unit [36]. Pumping station pressure reaches the highest value $(3.24 \mathrm{MPa})$ at a temperature of $2.1{ }^{\circ} \mathrm{C}$, which exceeds the current pressure by $0.32 \mathrm{MPa}$ (see Fig. 5). Such a slight change in pressure will not affect the characteristics of the pump. The research results show that the use of the cold flow method will reduce the amount of DARP by $94 \%$ and increase the time between overhauls in 8 times.

\section{Oil cooling equipment}

Heat exchangers and refrigerators are traditional equipment for oil cooling. However, in case of cooling the oil to low temperatures and paraffin precipitates intensively on the equipment and can cause its subsequent failure [37]. At the moment, the main challange with the use of the cold flow method is the lack of suitable equipment used in practice. Some inventions for cooling the oil flow are considered next.

Kellogg, Brown and Root (Halliburton) proposed apparatus "Paraffin absorber" for use in underwater systems. The flow is cooled as follows: the oil is passed through a loop-shaped tube, in which the external temperature of the wall is below the saturation temperature of the oil with paraffin, as a result of which the flow is cooled and the paraffin drops out. Developed DARP are removed by periodic cleaning of the pipe with scrapers and further transportation together with the stream in the form of a suspension that is resistant to sedimentation. The risk of gradual pipeline plugging and blockage of the scraper is the main disadvantage. In addition, the surface of the pipeline wall is covered with scars under the influence of a scraper, the number of places for paraffin adhesion increases (Fig. 6) [38].

There is a method of Instantaneous cooling proposed by Shell Western E\&P Inc. (Houston, Texas, USA) (Fig. 7). Oil mixes with gas and is passed through a choke coil, which leads to a sudden decrease in pressure and paraffin in the stream. The idea of this work is to use the JouleThomson effect to cool the flow [39].

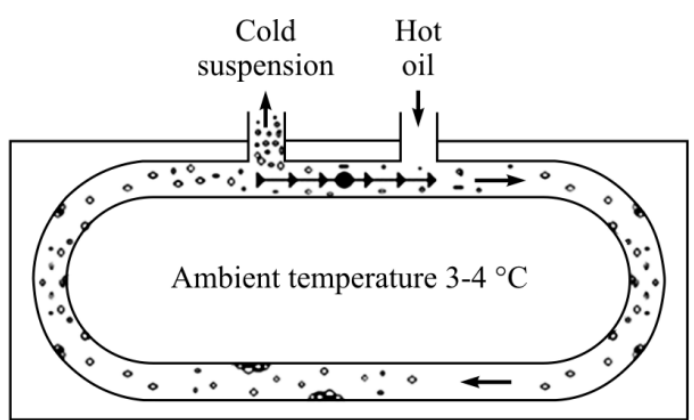

Fig. 6. Schematic view of the Paraffin Absorber apparatus

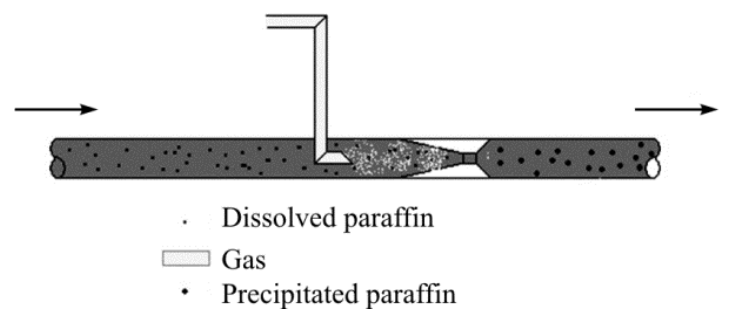

Fig. 7. Instantaneous Cooling Method scheme

According to the Injection of oil or solution method (C-FER Technologies, Edmonton, Canada) cooling is achieved by adding a cold oil or solvent recycle stream. It is also proposed to introduce an overcooled gas. To supercool the gas introduced into the oil flow, the Joule-Thomson expansion is used, which leads to the formation of a suspension [40]. All of these apparatus for cooling oil are patented, but not tested in real conditions.

\section{Conclusion}

The paper discusses the mechanisms of DARP development. Molecular diffusion is the main mechanism in the formation of paraffin deposits on the inner surface of the pipeline. Molecular diffusion is based on the transfer of dissolved paraffin components from the volume of oil to the wall of the pipeline. Paraffin precipitation is the result of a temperature gradient. Thus, an amount of DARP depends on the value of the temperature gradient. Methods based on the reduction of the temperature gradient effect are the most effective. These methods include cold flow.

The method involves transportation of oil cooled to ambient temperature; can find its 
application in pipelines, where the use of mechanical cleaning devices is not possible. These include variable-diameter pipelines, as well as pipelines that have constrictions, sharp turns, and other local resistances.

The hydraulic disign of the pipeline was carried out in the OLGA multiphase flow simulator in order to assess the effectiveness of the use of the cold flow method to prevent DARP precipitation. Calculation results show that the use of the cold flow method will reduce the DARP amount by $94 \%$ and increase the time between overhauls in 8 times.

Thus, cold flow method can significantly reduce production costs associated with the transportation of paraffin oil. However, there are no examples of its application in practice. At the moment, technological limitations associated with cooling process are the main disadvantage of the method proposed.

\section{References}

1. Semenyuk A.V., Kopteva A.V. Razrabotka sistemy monitoringa parafinovykh otlozheniy pri transportirovke neftyanykh potokov [Development of measurement system of $p$ araffin deposits in oil pipelines]. Sovremennaya nauka i praktika, 2016, no.9, pp.27-30.

2. Kazakova L.P., Kreyn S.E. Fiziko-khimicheskie osnovy proizvodstva neftyanykh masel [Physico-chemical basis for the production of petroleum oils]. Moscow, Khimiya, 1978, 320 p.

3. Loskutova Yu.V. et al. Podgotovka i transport problemnykh neftey (nauchno-prakticheskie aspekty) [Preparation and transport of problem oils (scientific and practical aspects)]. Tomsk, Izdatelskiy dom Tomskogo gosudarstvennogo universiteta, 2015, $135 \mathrm{p}$.

4. Lekomtsev A.V., Turbakov M.S. Otsenka rezultatov promyvok neftedobyvayushchikh skvazhin teplonositelem i uglevodorodnym rastvoritelem na mestorozhdeniyakh Nozhovskoy gruppy [Evaluation of results of flushing oil producing wells with coolant and hydrocarbon solvents at the Nozhovskaya group fields]. Nauchnye issledovaniya $i$ innovatsii, 2010, vol.4, no.2, pp.31.

5. Mordvinov A. et al. Effektivnost meropriyatiy po preduprezhdeniyu obrazovaniya i udaleniyu asfaltenosmoloparafinovykh otlozheniy pri ekspluatatsii neftedobyvayushchikh skvazhin v OOO "LUKOYL-PERM" [Effectiveness of measures to prevent formation and removal of sediments of asphaltenes, resins and paraffins while operating of oil wells in LUKOIL-PERM LLC]. Geologiya, geofizika i razrabotka neftyanykh i gazovykh mestorozhdeniy, 2008, no.8, pp.78-79.

6. Vyatkin K.A., Lekomtsev A.V., Martyushev D.A. Otsenka effektivnosti ochistki nasosnokompressornykh trub ot asfaltenosmoloparafinovykh otlozheniy teplovym metodom [Evaluation of the cleaning efficiency of pumpcompressor pipes from sediments of asphaltenes, resins and paraffins using the thermal method]. Ekologiya urbanizirovannykh territoriy, 2014, no.4, pp.96-100.

7. Shatokhina A.A. Vliyanie usloviy parafinoobrazovaniya na izmenenie raskhodnykh kharakteristik nefteprovoda: diplomnyy proekt [Influence of conditions of paraffin formation on the change in the flow characteristics of the pipeline: graduation project]. Tomsk, Natsionalnyy issledovatelskiy Tomskiy politekhnicheskiy universitet, Institut prirodnykh resursov. 2016.
8. Turbakov M.S., Lekomtsev A.V., Erofeev A.A. Opredelenie temperatury nasyshcheniya nefti parafinom dlya mestorozhdeniy Verkhnego Prikamya [Determination of paraffin saturation temperature of the Upper Kama oil fields]. Oil industry, 2011, no.8, pp.123-125.

9. Ivanova L.V., Burov E.A., Koshelev V.N. Asfaltosmoloparafinovye otlozheniya $\mathrm{v}$ protsessakh dobychi, transporta i khraneniya [Asphaltene-resin-paraffin deposits in the processes of oil production, transportation and storage]. Neftegazovoe delo, 2011, no.1, pp.268-284.

10. Ajayi O.E. Modelling of controlled wax deposition and loosening in oil and gas production systems. Norwegian University of Science and Technology, 2013, $106 \mathrm{p}$.

11. Borghi G.P., Correra S., Merino-Garcia D. Indepth investigation of wax deposition mechanisms. Proceedings OMC 2005 Offshore Mediterranean Conference and Exhibition. Ravenna, 2005.

12. Todi S., Klewicki J., Deo M.D. Elucidating the mechanisms of wax deposition. Proceedings of HOD 2004 International Conference on Heavy Organic Deposition. Los Cabos, 2004.

13. Ramirez-Jaramillo E., Lira-Galeana C., Manero O. Modeling wax deposition in pipelines. Petroleum science and technology, 2004, vol.22, no.7-8, pp.821-861. DOI: $10.1081 /$ LFT-120038726

14. Azevedo L.F.A., Teixeira A.M. A critical review of the modeling of wax deposition mechanisms. Petroleum Science and Technology, 2003, vol.21, no.3-4, pp.393-408. DOI: $10.1081 /$ LFT-120018528

15. Eskin D., Ratulowski J., Akbarzadeh K. Modelling wax deposition in oil transport pipelines. The Canadian Journal of Chemical Engineering, 2014, vol.92, no.6, pp.973-988. DOI: 10.1002/cjce.21991

16. Zlobin A.A., Mordvinov V.A., Yushkov I.R. Energiya aktivatsii uglevodorodov nefti kak kriteriy vybora ingibitorov parafinovykh otlozheniy [Energy of the activation of the hydrocarbons of oil as the criterion of the selection of inhibitors of the paraffin deposits]. Neft, gaz $i$ biznes, 2011, no.9, pp.50-54.

17. Hayduk W., Minhas B.S. Correlations for prediction of molecular diffusivities in liquids. The Canadian Journal of Chemical Engineering, 1982, vol.60, no.2, pp.295-299. DOI: 10.1002/cjce.5450600213 
18. Tronov V.P. Mekhanizm obrazovaniya smoloparafinovykh otlozheniy i borba s nimi [Mechanism of formation of smoloparaffin deposits and the fight against them]. Moscow, Nedra, 1966, 192 p.

19. Uoyld D. Khimicheskaya obrabotka dlya borby s otlozheniyami parafinov [Chemical treatment to control paraffin deposits]. Neftegazovye tekhnologii, 2009, no.9, pp.25-29.

20. Antoniali D.G. et al. Analiz sushchestvuyushchikh metodov borby s asfaltosmoloparafinovymi otlozheniyami pri dobyche nefti [Analysis of existing methods to combat asphalt-resin-paraffin deposits in oil production]. Stroitelstvo neftyanykh i gazovykh skvazhin na sushe i na more, 2011, no.9, pp.32-37.

21. Kolesnikov A.S., Nurdaulet A.N., Doszhanov K.A. Obzor issledovaniy vliyaniya magnitnogo polya na asfaltosmoloparafinovye otlozheniya [Review of studies of the influence of the magnetic field on asphalt-resin-paraffin deposits]. Mezhdunarodnyj studencheskij nauchnyj vestnik, available at: http://www.eduherald.ru/ru/article/view?id=25 (accessed 30 March 2018).

22. Makarevich A.V., Bannyy V.A. Metody borby s ASPO $\mathrm{v}$ neftedobyvayushchey promyshlennosti (obzor $\mathrm{v}$ dvukh chastyakh), part I [Methods against SARP in the oil industry (review in two parts) Part I]. Ekologiya promyshlennogo proizvodstva, 2012, no.4, pp.9-14.

23. Ustkachkintcev E.N., Melekhin S.V. Determination of the efficiency of wax deposition prevention methods. Perm Journal of Petroleum and Mining Engineering, 2016, no.18, pp.53-60. DOI: $10.15593 / 2224-9923 / 2016.18 .7$

24. Aksenov A.V. analiz metodov borby s asfaltosmolisto-parafinovymi otlozheniyami (ASPO) na stenkakh NKT i oborudovaniya [Analysis of methods against sediments of asphaltenes, resins and paraffins (SARP) on the walls of the tubing and equipment]. Problemy geologii $i$ osvoeniya nedr: Trudy XX Mezhdunarodnogo simpoziuma imeni akademika M.A. Usova studentov $i$ molodykh uchenykh, posvyashchennogo 120-letiyu so dnya osnovaniya Tomskogo politekhnicheskogo universiteta, 2016, vol.2, pp.819-821.

25. Merino-Garcia D., Correra S. Cold flow: A review of a technology to avoid wax deposition. Petroleum Science and Technology, 2008, vol.26, no.4, pp.446-459. DOI: $10.1080 / 10916460600809741$

26. Jemmett M.R., Deo M., Earl J., Mogenhan P. Applicability of cloud point depression to "cold flow". Energy \& Fuels, 2011, vol.26, no.5, pp.2641-2647. DOI: $10.1021 / \mathrm{ef} 2013908$

27. Kosyak D.V., Markin A.N. Opyt borby s otlozheniyami ASPO $\mathrm{v}$ podvodnykh truboprovodakh proekta "Sakhalin-2" [Control of wax deposition in subsea pipelines of Sakhalin-II project]. Territoriya "Neftegaz", 2011, no.6, pp.78-87.
28. Lebskiy D.S. Optimizatsiya temperaturnogo rezhima ekspluatatsii morskikh neftegazoprovodov [Optimisation of offshore oil and gas pipelines maintenance thermal regime]. Oborudovanie i tekhnologii dlya neftegazovogo kompleksa, 2009, no.1, pp.42-48.

29. Bryan S.H. Modelling of wax deposition in subsea pipelines. Johannesburg, 2016, $100 \mathrm{p}$.

30. Kjøraas M. Modelling of wax deposition in subsea pipelines. MSc Thesis, Norwegian University of Science and Technology, available at: https://www.yumpu.com/ en/document/view/23496494/modeling-of-wax-depositionalong-subsea-pipelines-ntnu (accessed 19 August 2018).

31. Volodchenkova O.Yu. Obespechenie proektnogo polozheniya podzemnykh magistralnykh nefteprovodov $\mathrm{v}$ zonakh vechnoy merzloty [Ensuring the design position of underground trunk pipelines in permafrost zones]. Moscow, 2007, $148 \mathrm{p}$.

32. Smirnova A.V. Osobennosti razvitiya perevozki nefti i nefteproduktov razlichnymi vidami transporta [Features of development of transportation of oil and petroleum products by various types of transport]. Vestnik Kazanskogo tekhnologicheskogo universiteta, 2012, vol.15, no.8, pp.303-307

33. Gulkov A.N., Lapshin V.D., Solomennik S.F., Gulkova S.G., Vasyanovich Yu.A., Nikitina A.V. O transportirovke nefti iz mestorozhdeniy, raspolozhennykh $\mathrm{v}$ vechnoy merzlote [On the transportation of oil from fields located in the permafrost]. Gornyy informatsionno-analiticheskiy byulleten (nauchnotekhnicheskiy zhurnal), 2014, no.OB4, pp.7-13

34. Ashmyan K.D., Volpin S.G., Kovaleva O.V. Razrabotka neftyanykh mestorozhdeniy $\mathrm{v}$ zone rasprostraneniya vechnoy merzloty [Development of oil fields in the permafrost zone]. Territoriya "Neftegaz", 2016, no.7-8, pp.88-95.

35. OLGA version 2014.1 User Manual. Schlumberger, 2014.

36. Polishchuk Yu.M., Yashchenko I.G. Issledovanie vyazkosti neftey $\mathrm{v}$ zavisimosti ot temperatury [The study of oil viscosity depending on temperature]. Neft. Gaz. Novatsii, 2003, no.5, pp.31-32.

37. Sakhabutdinov R.Z., Korotkova O.Yu., Fattakhov R.B. O vozmozhnosti okhlazhdeniya tovarnoy nefti $\mathrm{s}$ sipolzovaniem absorbtsionnoy kholodilnoy mashiny [About the possibility of commercial oil cooling using absorption chillers]. Oborudovanie $i$ tekhnologii dlya neftegazovogo kompleksa, 2012, no.6, pp.31-34.

38. Bidmus H.O., Mehrotra A.K. Solids deposition during "cold flow" of wax - solvent mixtures in a flowloop apparatus with heat transfer. Energy \& Fuels, 2009, vol.23, no.6, pp.3184-3194. DOI: 10.1021/ef900224r

39. Knowles W.T. Jr Choke cooling waxy oil: pat. 4697426 USA. 1987.

40. Hutton G.J., Kruka V.R. Existing cold flow projects deep star. Report 5201-3a. Washington, 2001. 


\section{Библиографический список}

1. Семенюк А.В., Коптева А.В. Разработка системы мониторинга парафиновых отложений при транспортировке нефтяных потоков // Современная наука и практика. - 2016. - №. 9. - С. 27-30.

2. Казакова Л.П., Крейн С.Э. Физико-химические основы производства нефтяных масел. - М.: Химия, 1978. -320 c.

3. Подготовка и транспорт проблемных нефтей (научно-практические аспекты) / Ю.В. Лоскутова [и др.]. - Томск: Издательский дом Томск. гос. ун-та, 2015. - $135 \mathrm{c}$

4. Лекомцев А.В., Турбаков М.С. Оценка результатов промывок нефтедобывающих скважин теплоносителем и углеводородным растворителем на месторождениях Ножовской группы // Научные исследования и инновации. - 2010. - Т. 4, №. 2. - С. 31.

5. Эффективность мероприятий по предупреждению образования и удалению асфальтеносмолопарафиновых отложений при эксплуатации нефтедобывающих скважин в ООО «ЛУКОЙЛ-ПЕРМЬ» / А. Мордвинов [и др.] // Геология, геофизика и разработка нефтяных и газовых месторождений. - 2008. - № 8. - С. 78-79.

6. Вяткин К.А., Лекомцев А.В., Мартюшев Д.А. Оценка эффективности очистки насосно-компрессорных труб от асфальтеносмолопарафиновых отложений тепловым методом // Экология урбанизированных территорий. - 2014. - № 4. - С. 96-100.

7. Шатохина А.А. Влияние условий парафинообразования на изменение расходных характеристик нефтепровода: дипломный проект / Нац. исслед. Томск. политехн. ун-т, Институт природных ресурсов. - Томск, 2016.

8. Турбаков М.С., Лекомцев А.В., Ерофеев А.А. Определение температуры насыщения нефти парафином для месторождений Верхнего Прикамья // Нефтяное хозяйство. -2011 . - № 8. - С. 123-125.

9. Иванова Л.В., Буров Е.А., Кошелев В.Н. Асфальтосмолопарафиновые отложения в процессах добычи, транспорта и хранения // Нефтегазовое дело. 2011. - № 1. - C. 268-284.

10. Ajayi O.E. Modelling of controlled wax deposition and loosening in oil and gas production systems. - Norwegian University of Science and Technology, 2013. - 106 p.

11. Borghi G.P., Correra S., Merino-Garcia D. Indepth investigation of wax deposition mechanisms // Proceedings OMC 2005 Offshore Mediterranean Conference and Exhibition. - Ravenna, 2005.

12. Todi S., Klewicki J., Deo M.D. Elucidating the mechanisms of wax deposition // Proceedings of HOD 2004 International Conference on Heavy Organic Deposition. - Los Cabos, 2004.

13. Ramirez-Jaramillo E., Lira-Galeana C., Manero O. Modeling wax deposition in pipelines // Petroleum science and technology. - 2004. - T. 22, № 7-8. - C. 821-861. DOI: $10.1081 /$ LFT-120038726

14. Azevedo L.F.A., Teixeira A.M. A critical review of the modeling of wax deposition mechanisms // Petroleum Science and Technology. - 2003. - T. 21, № 3-4. P. 393-408. DOI: 10.1081/LFT-120018528

15. Eskin D., Ratulowski J., Akbarzadeh K. Modelling wax deposition in oil transport pipelines // The Canadian Journal of Chemical Engineering. - 2014. - T. 92, № 6. P. 973-988. DOI: 10.1002/cjce.21991

16. Злобин А.А., Мордвинов В.А., Юшков И.Р. Энергия активации углеводородов нефти как критерий выбора ингибиторов парафиновых отложений // Нефть, газ и бизнес. - 2011. - № 9. - С. 50-54.

17. Hayduk W., Minhas B. S. Correlations for prediction of molecular diffusivities in liquids // The Canadian Journal of Chemical Engineering. - 1982. - Vol. 60, № 2. - P. 295-299. DOI: 10.1002/cjce.5450600213

18. Тронов В.П. Механизм образования смолопарафиновых отложений и борьба с ними. М.: Недра, 1966. - 192 с

19. Уойлд Д. Химическая обработка для борьбы с отложениями парафинов / пер. с англ. В. Клепинина // Нефтегазовые технологии. - 2009. - № 9. - С. 25-29.

20. Анализ существующих методов борьбы с асфальтосмолопарафиновыми отложениями при добыче нефти / Д.Г. Антониали [и др.] // Строительство нефтяных и газовых скважин на суше и на море. -2011 . - № 9. C. 32-37.

21. Колесников А.С., Нурдаулет А.Н., Досжанов К.А. Обзор исследований влияния магнитного поля на асфальтосмолопарафиновые отложения [Электронный pecypc] // Международный студенческий научный вестник. - URL: http://www.eduherald.ru/ru/article/ view?id=25 (дата обращения: 30.03.2018).

22. Макаревич А.В., Банный В.А. Методы борьбы с АСПО в нефтедобывающей промышленности (обзор в двух частях). Часть I // Экология промышленного производства. - 2012. - № 4. - С. 9-14.

23. Устькачкинцев Е.Н., Мелехин С.В. Определение эффективности методов предупреждения асфальтеносмолопарафиновых отложений // Вестник Пермского национального исследовательского политехнического университета. Геология, нефтегазовое и горное дело. - 2016. - № 18. - С. 53-60. DOI: $10.15593 / 2224-9923 / 2016.18 .7$

24. Аксенов А.В. Анализ методов борьбы с асфальтосмолистопарафиновыми отложениями на стенках НКТ и оборудования // Проблемы геологии и освоения недр: тр. ХХ Междунар. симп. им. акад. М.А. Усова студентов и молодых ученых, посвящ. 120-летию со дня основания Томск. политехн. ун-та, 4-8 апреля 2016 г. - Томск, 2016. - Т. 2. - С. 819-821. 
25. Merino-Garcia D., Correra S. Cold flow: A review of a technology to avoid wax deposition // Petroleum Science and Technology. - 2008. - Vol. 26, № 4. P. 446-459. DOI: 10.1080/10916460600809741

26. Applicability of cloud point depression to «cold flow» / M.R. Jemmett, M. Deo, J. Earl, P. Mogenhan // Energy \& Fuels. - 2011. - Vol. 26, № 5. - P. 2641-2647. DOI: $10.1021 / \mathrm{ef} 2013908$

27. Косяк Д.В., Маркин А.Н. Опыт борьбы с отложениями АСПО в подводных трубопроводах проекта «Сахалин-2» // Территория «Нефтегаз». 2011. - № 6. - С. 78-87.

28. Лебский Д.С. Оптимизация температурного режима эксплуатации морских нефтегазопроводов // Оборудование и технологии для нефтегазового комплекса. - 2009. - № 1. - С. 42-48.

29. Bryan S.H. Modelling of wax deposition in subsea pipelines. - Johannesburg, 2016. - 100 p.

30. Kjøraas M. Modelling of wax deposition in subsea pipelines. MSc Thesis, Norwegian University of Science and Technology [Электронный pecypc]. URL: https:/www.yumpu.com/en/document/view/23496494/ modeling-of-wax-deposition-along-subsea-pipelines-ntnu (дата обращения: 19 августа 2018).

21. Володченкова О.Ю. Обеспечение проектного положения подземных магистральных нефтепроводов в зонах вечной мерзлоты. - М., 2007. - 148 с.

32. Смирнова А.В. Особенности развития перевозки нефти и нефтепродуктов различными видами транспорта // Вестник Казанского технологического университета. 2012. - T. 15, № 8. - C. 303-307.
33. О транспортировке нефти из месторождений, расположенных в вечной мерзлоте / А.Н. Гульков, В.Д. Лапшин, С.Ф. Соломенник, С.Г. Гулькова, Ю.А. Васянович, А.В. Никитина // Горный информационноаналитический бюллетень (научно-технический журнал). 2014. - № OB4. - C. 7-13.

34. Ашмян К.Д., Вольпин С.Г., Ковалева О.В. Разработка нефтяных месторождений в зоне распространения вечной мерзлоты // Территория «НЕФТЕАЗ». - 2016. - № 7-8. - С. 88-95.

35. OLGA version 2014.1 User Manual. Schlumberger, 2014.

36. Полищук Ю.М., Ященко И.Г. Исследование вязкости нефтей в зависимости от температуры // Нефть. Газ. Новации. - 2003. - № 5. C. 31-32.

37. Сахабутдинов Р.З., Короткова О.Ю., Фаттахов Р.Б. О возможности охлаждения товарной нефти с сипользованием абсорбционной холодильной машины // Оборудование и технологии для нефтегазового комплекса. - 2012. - № 6. - С. 31-34.

38. Bidmus H.O., Mehrotra A.K. Solids deposition during «cold flow» of wax - solvent mixtures in a flowloop apparatus with heat transfer // Energy \& Fuels. 2009. - Vol. 23, № 6. - P. 3184-3194. DOI: $10.1021 / \mathrm{ef} 900224 \mathrm{r}$

39. Knowles W.T. Jr. Choke cooling waxy oil: pat. 4697426 USA. - 1987

40. Hutton G.J., Kruka V.R. Existing cold flow projects deep star: Report 5201-3a. - Washington, 2001.

Please cite this article in English as:

Ilyushin P.Yu., Lekomtsev A.V., Ladeyshchikova T.S., Rakhimzyanov R.M. The efficiency assessment of the "Cold Flow" method against the deposition of asphaltenes, resins and paraffins. Perm Journal of Petroleum and Mining Engineering, 2018, vol.18, no.1, pp.53-62. DOI: $10.15593 / 2224-9923 / 2018.3 .5$

Просьба ссылаться на эту статью в русскоязычных источниках следующим образом:

Оценка эффективности метода «холодный поток» в борьбе с асфальтеносмолопарафиновыми отложениями / П.Ю. Илюшин, А.В. Лекомцев, Т.С. Ладейщикова, Р.М. Рахимзянов // Вестник Пермского национального исследовательского политехнического университета. Геология. Нефтегазовое и горное дело. - 2018. - Т.18, №1 . - C.53-62. DOI: 10.15593/2224-9923/2018.3.5 